\title{
FREIGHT FORWARDERS, BROKERAGE, AND SHIPPING CONFERENCE AGREEMENTS: IMPLICATIONS OF THE ISBRANDTSEN DOCTRINE
}

Maritime shipping conferences ${ }^{1}$ have for many years regulated the payment of marine freight brokerage. ${ }^{2}$ The Federal Maritime Board has accepted this conference practice and extended federal antitrust exemption to it under statutory powers granted the Board in the Shipping Act of $1916 .^{3}$ The Supreme Court's application of Section 14 Third of the Shipping Act in Federal Maritime Board v. Isbrandisen ${ }^{4}$ suggests that the Board's policy approving conference brokerage rules requires reconsideration where such rules affect independent liner competitors of conferences.

Prior to Isbrandtsen the Federal Maritime Board had a free hand in the formulation of national maritime policy concerning conference activities. Applying the doctrine of primary jurisdiction, the courts were loath to pit their judgment against that of the Board. ${ }^{5}$ In Isbrandtsen the Court struck down a Boardapproved conference dual-rate shipping contract system the purpose and effect of which was the elimination of independent competition on the conference's route. This decision overturned a long standing Board policy approving dual rates, and, by implication, the elimination in this manner of independents. The Court held that Section 14 Third of the Shipping Act prohibits dual rate contracts where their effect upon independent competition is "predatory" in purpose and effect. ${ }^{6}$ The Board argued unsuccessfully that its powers under the act permitted approval of any conference practice not specifically outlawed by the act. Isbrandisen suggests that the Court reads section 14 as a further limitation upon the Board's power to give conference activities antitrust exemption. The case would appear to stand for the proposition that conference action is limited

${ }^{1}$ Shipping conferences are loosely organized associations of steamship companies operating regularly scheduled sailings on a trade route. Each route has its own conference, and many steamship companies participate in more than one conference. Conference operations are confined to liner commerce. Maritime commerce is broadly divided into two categories: tramp and liner operations. Tramps carry primarily bulk cargoes, liners primarily dry package cargo. Because of the difference in cargoes, liners are considered non-competitive. See McGee, Ocean Freight Rate Conferences and the American Merchant Marine, 27 U. CHr. L. REv. 191, 205 (1960).

2 See note 15 infra, for a discussion of the Board's definition of brokerage.

${ }^{3} 64$ Stat. 1274, 1277 (1950), 46 U.S.C. $\$ 814$ (1958). Section 15 of the act provides for the filing of conference agreements with the Board. The Board may disapprove, cancel, or modify any filed agreement found by it "unjustly discriminatory or unfair as between carriers, shippers, exporters, importers or ports ... . or to operate to the detriment of the commerce of the United States." Conference agreements approved under this section are exempt from the provisions of the antitrust laws.

1356 U.S. 481 (1958).

see Comment, Primary Jurisdiction and the Applicability of Antitrust Remedies in the Shipping Indusiry, 26 U. CEI. L. REv. 598 (1959).

. 356 U.S. 481, 492-93 (1958). 
to agreements controlling competition among conference members and may not be used to control competition within the industry generally. Read in this way, the Board's powers of approval are limited to conference practices affecting only competition within the conference structure itself. Application of this view of Isbrandtsen to conference brokerage rules indicates that Board policy statements approving brokerage regulations may be too broad. A study of the Board's position is especially appropriate today in light of the uncertain status of brokerage policy, and of indications that Board attitudes in this area are undergoing change. ${ }^{7}$

\section{Brokerage Practices and Their Effect on Liner CoMpetition}

Brokerage is the fee paid by carriers to independent middlemen-brokers for securing cargo for the carrier's ships. Brokerage provides an incentive to the broker to direct cargo to the paying carrier. ${ }^{8}$ Typically brokerage is estimated as a percentage of the freight charged on the directed shipment. On American trade routes this percentage traditionally has been $1 \frac{1}{4}$ per cent of the freight. ${ }^{9}$ Liner commerce has for many years been overtonnaged and ships in recent years have rarely sailed with full cargoes. ${ }^{10}$ For this reason, brokers controlling the designation of carriers in this industry are in a particularly strategic position. They are able to take advantage of actual or latent competition among carriers to increase their brokerage earnings. Much of the litigation before the Board in recent years has centered around the interrelationship of carrier competition and brokerage. ${ }^{11}$

${ }^{7}$ See notes 49 to 54 infra, and accompanying text.

8 "The overwhelming conclusion drawn from the record is that brokerage is primarily a competitive device, utilized by the carriers to attract to themselves as much as possible of the traffic as to which the forwarders, by authorization of their shipper clients, control the routing." Examiner's Preliminary Report, Docket No. 831 F.M.B. at 32 (March, 1960).

- Brokerage rates in other parts of the world tend to be higher than American rates. See Appendix, European Brokerage Rates, Hearings on Freight Forwarders and Brokers, 84th Cong. 1st \& 2d Sess. (1956). There is considerable evidence that brokerage rates on American routes increase when there is competition between an independent and a conference. Hearings Before the Special Subcommittee on Steamship Conferences of the House Committee on the Merchant Marine and Fisheries, 86th Cong., 1st. Sess., pt. I, at 13-14 (1959) (statement of Clarence Morse, Chairman, Federal Maritime Board); pt. II, at 356-57 (testimony of Mr. Wierda, a shipping company executive); at 443 (testimony of Mr. Coron, a freight forwarder).

${ }^{10}$ Cargo capacity in liner commerce has exceeded actual cargo by 44 per cent in recent years. Comment, 11 Stan. L. Rev. 136, 138-39 (1958).

11 These cases are discussed in part II infra. In other cases the Board has been concerned with shippers collecting brokerage under the guise of being forwarders. Samuel Kaye-Collection of Brokerage/Misclassification, 5 F.M.B. 385 (1958); Brokerage on Ocean Freight-Max Lepack, 5 F.M.B. 435 (1958; Luis (Louis) A. Pereirra-Collection of Brokerage, 5 F.M.B. 400 (1958). The Board has found this practice a violation of section 10 of the act, which prohibits the obtaining of water transportation at less than the applicable charge. In American Union Transport v. River Plate \& Brazil Conf., 5 F.M.B. 216 (1958), cert.denied, 358 U.S. (1958), the Board found that forwarders rendering forwarding services without charge, relying on brokerage for compensation, also violated section 16 by permitting shippers to receive transportation at less than the applicable rate. 
Industry practice regarding brokerage is complicated by the relationship that exists between freight brokers and freight forwarders. The freight forwarder, similar in many respects to his domestic rail and air forwarder counterparts, ${ }^{12}$ is an independent shippers' agent administering and supervising the delivery, documentation and other administrative details of export shipment. ${ }^{13}$ In many cases the freight forwarder and broker are identical business entities. Forwarders engage in brokerage activities as an ordinary incident of their forwarding services while administering a shipment. The result has been a duality in the business relationships and sources of income of the forwarding industry. ${ }^{14} \mathrm{On}$ some shipments forwarders act as both forwarding agents for shippers and brokers for carriers. On others, the shipper himself arranges water carriage for the goods and the forwarder performs his services exclusively for the shipper as a forwarding agent. Industry practice does not adhere to any rigid separation of forwarder and broker functions, and the practice has developed of carriers paying brokerage on every shipment handled by a forwarder. ${ }^{25}$ This payment of "automatic" brokerage is a competitive device within the liner industry. It provides an added incentive to forwarders, as brokers, to direct cargo under their control to paying lines, and enables conference carriers to evade conference rules establishing uniform maximum rates at which brokerage can be paid by member lines.

The conferences have not been unaware of the competitive use of brokerage in the industry, or of its potentially destructive effect upon conference structure. Conferences exist for the purpose of controlling the price at which liner shipping services will be offered to shippers. ${ }^{16}$ Control is accomplished by a cartel-like

12 For a legal history of the development of domestic forwarding, see Elggren, What Part Shall Freight Forwarders Have in the Development of the Air Freight Industry?, 14 J. OF AIR L. \& Covar. 170, 171-96 (1947).

13 See Mutr, The Foreign Freight Forwarder (1957); Port of New York Freight Forwarder Investigation, 3 U.S.M.C. 1957 (1949).

14 Forwarders received $\$ 11,109,181$ in brokerage payments in 1957 . This amount was 31 per cent of the industry's net income in that year. Examiner's Preliminary Report, Docket No. 831 F.M.B. at 12-13 (March, 1960).

${ }^{15} \mathrm{Id}$. at 26, 30. Brokerage is not defined in the Shipping Act. The Board has adopted the definition that brokerage, properly earned, "is compensation for securing cargo for the ship." Agreements and Practices Re Brokerage, 3 U.S.M.C. 170, 172 (1949). The forwarders have argued that forwarding services, as such, are beneficial to the carriers and thus entitle them to brokerage on every shipment handled. See Hearings on Freight Forwarders and Brokers, supra note 9. See also Examiner's Preliminary Report, Docket No. 831 F.M.B. at 31-32 (March, 1960), for a summary of the positions taken by forwarders, conferences and the Board. Even in Agreements and Practices Re Brokerage, 3 U.S.M.C. 170 (1949), the Board case most favorable to forwarders, the Board found that forwarder services are "primarily for shippers, and the carrier's benefit is incidental." Id. at 175. This view was recently affirmed in American Union Transp., Inc. v. River Platte \& Brazil Conf., 5 F.M.B. 216 (1957); American Union Transp., Inc. v. United States, 257 F.2d. 607 (1958), cert. denied, 358 U.S. 828 (1958). Pending legislation would adopt the forwarder's view and redefine brokerage so as to authorize payment on every forwarder-handled shipment. H. R. REp. No. 798, 86th Cong., 1st Sess. (1959) (H.R 5068, Providing for the Licensing of Independent Foreign Freight Forwarders).

${ }^{16}$ See McGee, supra note 1, at 210-13. 
structure establishing uniform conference rates for these services. ${ }^{17}$ Insofar as alternative shipping services are unavailable or unsuited to shipper needs, the conferences are able to maintain their rates. ${ }^{18}$ Conference organization eliminates direct price competition among member lines, thereby facilitating the fixing of rates by agreement. Although conference carriers eschew direct price competition, they remain to an unknown extent competitors for the cargo actually moving in their trade. ${ }^{19}$ The essentially fixed costs of vessel operation provide an incentive to carriers to maximize the cargo loads of their vessels..$^{20}$ The latent competitive forces within conferences create a problem of internal stability which brokerage competition among member lines would exacerbate. Conferences have for the most part not developed techniques for allocating available cargo supply among member lines. ${ }^{21}$ Brokerage payment provides an alternative to price competition, enabling one conference line to secure an increased share of the cargo in a given trade. By offering to pay brokerage on all forwarder-handled shipments the paying carrier induces forwarder-brokers to direct the cargo which they control to that carrier. In an extreme case the diversion of cargo to one conference member, to the detriment of other conference carriers, might result in the resumption of price competition. It is therefore in the conferences' interest to minimize brokerage competition among member lines.

The conferences have nullified the competitive effect of brokerage in much the same way as they control price competition. Typically conference rules establish uniform maximum rates at which brokerage may be paid by member lines. Uniformity avoids competitive advantages achievable through differentials in payment. Uniformity, however, does not wholly eliminate brokerage as a competitive device. The forwarder-broker relationship provides a means for evading the conference uniformity rules. Brokerage remains competitive when any carrier on a route, whether conference or independent, is willing to make automatic payment on all forwarder-handled shipments. The willingness of any one carrier to make automatic payment compels payment by its competitors. ${ }^{22}$

${ }^{17}$ Professor Marx, a leading authority on conference structure, considers conferences to be cartels. Marx, INTERNational ShIPping Cartels: A Study in INDUSTrial Self-RegulaTION BY ShIPpING Conferences (1935). See also McGee, supra note 1, at 196-204.

18 Conference rates are, of course, subject to outside economic pressures and are thus limited by (1) tramp competition, (2) independent liner competition, and (3) the rates that particular commodities will bear in relation to their overseas markets.

${ }^{19}$ Cf. McGee, supra note 1 , at 230-31.

${ }^{20}$ MARX, op. cit. supra note 17 , at 20-21.

${ }_{21}$ Professor McGee suggests that the infrequency with which conferences resort to pooling arrangements, sailing quotas or other allocating devices indicates that they are considered unnecessary and that only price competition has a significant effect in the industry. McGee, supra note 1, at 229-31. But see, Testimony of Alex Cocke, Vice-President of Lykes Bros. Steamship Company, Hearings before the Special Subcommittee on Steamship Conferences of the House Commitlee on the Merchant Marine and Fisheries, 86 Cong. 1st Sess., pt. I at 263 (1959). Mr. Cocke believes that considerable service competition exists between conference members.

22 Examiner's Preliminary Report, Docket No. 831 F.M.B. at 26, 33 (March, 1960). 
The alternative for a non-paying carrier is discrimination by the forwarders on those cargoes controlled by them. Few carriers are in a position to ignore this factor.

The desirability of preventing evasion of the conference rules, and the diffculty of policing the numerous transactions between forwarders and conference carriers, have led many conferences to adopt rules prohibiting all brokerage payments..$^{23}$ Prohibition not only prevents abuses of conference brokerage rules by members, but also reduces costs to conference members insofar as bona fide brokerage claims ${ }^{24}$ are denied with the rest. Industry practice indicates that conferences are able to establish prohibitory rules only where no effective competition exists between conferences and independents, or between competing conferences. ${ }^{25}$ The existence of competition tends to force conference compliance with the prevailing rate for brokerage. In cases where there is a high degree of conference overlap in route markets, a tacit acceptance of the traditional $1 \frac{1}{2}$ per cent brokerage seems to have resulted. ${ }^{26}$

The main thrust of conference brokerage regulation has been the elimination of brokerage competition among conference members. In one reported case, ${ }^{27}$ however, the conference rule was designed and applied as a competitive device against an independent steamship line competitor of the conference. Conferences have found direct price competition with independents costly and difficult. Engaging in price competition is, of course, directly contrary to the conference purpose since it results in rate cutting. Independents frequently follow a policy of setting their rates at a fixed percentage below those of the conference on the routes on which they compete. ${ }^{28}$ It is difficult for conferences to meet such a competitive policy without abandoning conference rates. ${ }^{29}$ Conferences have

${ }^{23}$ Conferences barring the payment of brokerage through their agreements are listed in Agreements and Practices Re Brokerage, 3 U.S.M.C. 170, 173 (1949). The practice appears to be widespread.

21 For a discussion of Board definitions of brokerage, see note 15 supra.

${ }^{25}$ The conference rule in Pacific Coast Westbound Conf. (Agreement No. 7790), 2 U.S.M.C. 775 (1946), illustrates the point. Conference traffic was placed in two categories: local and overland. Local traffic originated in the geographic area west of the Rockies, and could not be shipped otherwise than from Pacific coast ports. Overland traffic originated in the area east of the mountains and was therefore competitive with ports on the Atlantic and Gulf coasts. The conference did not pay brokerage on local traffic, but did pay $1 \frac{1}{4}$ per cent on overland shipments, which were subject to competition of conferences on the Gulf and Atlantic. The rate was comparable to that paid by Atlantic and Gulf conferences. The inference is that the conference rule was the result of competitive pressure. It is doubtful that conferences can or would refuse brokerage in a competitive situation. Such a refusal would only worsen the competitive position of the conference.

${ }^{26}$ This may be inferred, e.g., from the failure of the competing conferences in Agreement 7790, supra note 25 , to engage in brokerage competition for the overland traffic.

${ }^{27}$ Pacific Coast European Conf., 5 F.M.B. 225 (1957).

${ }^{28}$ The policy of Isbrandtsen S.S.Co. is typical. Isbrandtsen was generally understood in the trade to be undercutting the quoted conference price by 10 per cent. Federal Maritime Board v. Isbrandtsen, 356 U.S. 481, 485 (1958).

${ }^{29} \mathrm{Id}$. at $485-87$. 
found control over the demand for liner services a more effective device for meeting and preventing independent competition. Prior to the Shipping Act the deferred rebate successfully achieved conference control over available cargo. Shippers engaged in exclusive dealing contracts with conferences in return for lower rates. The conference charged the normal rate and deferred the rebated lower charge thereby ensuring continued shipper adherence to the contract. Deferred rebates were prohibited by the act. ${ }^{30}$ The dual rate system condemned in Isbrandtsen operated on a similar principle. Shippers engaging to ship exclusively aboard conference vessels received a lower rate. The main difference between the two devices was that under dual rates the shipper benefited immediately from his bargain since he paid only the lower rate. Although dual rate contracts frequently contained liquidated damage provisions, they proved less effective than deferred rebates in controlling shippers. Indeed one of the great struggles in recent years has been the conferences' attempt to plug loopholes by which shippers evaded their dual rate obligations to ship aboard conference vessels. ${ }^{31}$ Exclusive dealing contracts, whether deferred rebate or dual rate, serve the same purpose. Under either, the shipper abandons his right to choose a non-conference carrier for his goods. The result is the denial to independent lines of all cargo covered by such contracts.

To the extent that conferences are able to compel shipper compliance with such exclusive dealing arrangements, conferences are able to nullify the competitive impact of independent competition. First, the conference revenue is not decreased as to controlled cargo since such cargo continues to move aboard conference vessels. Secondly, the denial of controlled cargo tends to increase conference competitive pressure against independents by denying the independent an effective cargo base upon which to conduct his operation. When cargo is unavailable on a route as a result of exclusive dealing contracts, independents are forced either to abandon independent competition and join the conference, or to abandon the route for one more favorable to their operation.

Similar results can be achieved through brokerage rules. Conferences dominate routes on which they operate in terms of number of sailings, cargo capacity and, generally, gross cargo tonnage actually carried. Conference dominance continues even in cases where independents have made severe inroads upon the conference position. ${ }^{32}$ As a result, conference brokerage tends to be of markedly

3072 Stat. 574 (1958), 46 U.S.C. $\S 812$ (1958).

${ }^{31}$ One device enabling shippers to evade the dual rate contract was shipping in the forwarder's name and receiving through bills of lading issued by the forwarder. The Board found this an unjust practice in the Port of New York Freight Forwarder Investigation, 3 U.S.M.C. 157 (1949).

${ }^{32}$ Even in the situation presented in the Isbrandisen case where the competition of the independent, Isbrandtsen, had a severe impact upon the conference, the conference retained 70 per cent of the cargo carried on the route and made 89 per cent of the sailings. The greater number of conference vessels and sailings indicates that in most cases conference carriers will continue to move a preponderance of the cargo. 
greater importance as a source of revenue to forwarder-brokers than that of independent lines. Where conferences pay "automatic brokerage," as is the practice on routes on which competition exists, the inducement to the forwarderbrokers to retain conference patronage is particularly strong. As a result of the relatively greater importance of conference brokerage, the threat of its loss is an effective device coercing forwarder-brokers into not dealing with independent lines. ${ }^{33}$

In the Pacific Coast European Conf. ${ }^{34}$ case this coercive pressure was used by the conference to prevent brokers from dealing with a conference competitor. The conference provided in its rules that member lines would pay brokerage only to brokers on an approved conference list. ${ }^{35}$ Members were forbidden to pay brokerage to unapproved brokers. In 1953, Mitsui S.S. Lines entered the trade as an independent conference competitor. The conference amended its rules so as to blacklist and strike from the approved list "any broker solicit[ing] for, or receiv[ing] brokerage from, a nonconference competitor. ... ${ }^{36}$ The effect of this provision was to force brokers to choose between dealing with the conference or Mitsui. As a practical matter, the greater amount and importance of conference brokerage had the effect of channeling all brokercontrolled cargo to the conference. The independent was denied access to cargo in the hands of brokers in much the same manner as was accomplished by dual rates.

Here again the forwarder-broker duality complicated the situation. The conference applied its blacklisting against any forwarder receiving brokerage from the independent regardless of whether or not the forwarder solicited for the independent. ${ }^{37}$ Forwarders shipping by an independent carrier at the shipper's order and receiving automatic brokerage from the independent were struck from the conference-approved list just as were forwarders actively soliciting for the independent. Forwarders naturally began to refuse to handle cargo destined for the independent for fear that they would be blacklisted..$^{38}$ The conference

33 "Because of the much greater relative importance of the income received as brokerage from the conference lines it was the unanimous position of the forwarder-broker witnesses that their only practical choice would be to refuse to handle, as either forwarder or broker, any shipments moving on a nonconference vessel." Pacific Coast European Conf., 5 F.M.B. 225, 239 (1957).

345 F.M.B. 225 (1957).

${ }^{35}$ Pacific Coast Tariff No. 12. Rule 21, Freight Brokerage. Id. at app. B.

${ }^{36}$ Ibid.

27 Id. at 232. (testimony of conference chairman).

${ }^{38}$ It might be thought that whenever an independent liner substantially undercuts conference rates, shippers and forwarders would take advantage of these rates by arranging for the forwarder's compensation to come from the shipper. Such an arrangement might take two forms: (1) the forwarder could decline all brokerage payments from the independent, thus hoping to avoid conference blacklisting, and the shipper would reimburse the forwarder for lost brokerage from the independent, or (2) the forwarder could accept independent brokerage, suffer black-listing by the conference and be reimbursed by the shipper in an amount equal to the loss of conference patronage and brokerage caused by the blacklisting. It is, however, un- 
rule as applied not only coerced brokers, but also, by denying independent shippers forwarding services, tended to force shippers to abandon the use of independent liner services.

\section{Policy of the Federat Maritine Board toward Various Forms of CONFERENCE BROKERAge RegUlattons}

Throughout its history the Federal Maritime Board and its predecessor agencies have generally adhered to a policy approving conference regulation of brokerage. The Board has not distinguished between conference regulations the purpose and effect of which has been the elimination of independent liner competition, and those affecting competition only within the conferences themselves. The decision in Isbrandtsen appears to rest upon this distinction, suggesting that the breadth of Board approval may be unwarranted.

From 1923 to 1946 the Board's policy was tacitly expressed in its approval of conference agreements containing brokerage rules. A 1936 dictum $^{39}$ suggests that Board approval during this period extended not only to uniform rates and prohibitory conference rules, but also to conference use of brokerage as a competitive device against independents. ${ }^{40}$ In Pacific Coast Westbound Conf. Agreement 7790,41 decided in 1946, the brokers successfully challenged a conference rule prohibiting all brokerage payments on a portion of the conference traffic. The conferences resisted this shift in Board policy. In the resulting general investigation of brokerage, Agreements and Practices Re Brokerage, ${ }^{42}$ the Board affirmed its earlier decision on the ground that prohibition of brokerage was detrimental to American foreign commerce. The issue in these and other brokerage cases was not the general question of the validity of brokerage rules,

likely that shippers and forwarders would employ either of these devices. In all probability, arrangement (1) would simply not work. Conferences could easily frustrate it by applying its blacklisting regulation to the forwarder in spite of his nonacceptance of brokerage from the independent, on the ground that the forwarder was nevertheless "dealing with" an independent liner.

In most situations the loss to the forwarder resulting from blacklisting would be so great that the shipper could not afford to provide the amount of reimbursement called for under arrangement (2). This is largely because the forwarder could not afford to be concerned solely with the immediate effects of loss of conference business but would have to consider the likelihood of long range detriment. The magnitude of this long range detriment would, in most situations, be increased by the fact that even on routes where an independent liner is competing, conferences carry a substantial majority of the cargo, and by the ever present danger that the independent carrier, typically a transitory operator, would pull out of the route if more lucrative cargoes became available elsewhere.

${ }^{39}$ In re Gulf Brokerage and Forwarding Agreements, 1 U.S.S.B.B. 533, 535 (1936).

${ }^{40}$ Whether conference brokerage agreements in this period included brokerage rules affecting independent non-conference competitors is not known. This information is contained in the actual conference agreements filed with the Board for approval, and a search of these agreements would be required to discover what particular rules conferences were then employing.

42 U.S.M.C. 775 (1946). 12.3 U.S.M.C. 170 (1949). 
but rather the narrow issue of whether conferences could prohibit brokerage altogether. Nevertheless, these cases do indicate the Board's policy regarding brokerage and provide a basis on which this policy can be analyzed.

The rule anounced in Agreements and Practices Re Brokerage condemned conference agreements forbidding all brokerage regardless of the circumstance. ${ }^{43}$ This, the Board said, injured the forwarding industry by denying it earned fees, and was, therefore, detrimental to commerce. ${ }^{44}$ Such agreements would not be approved and conferences were to comply by eliminating such rules from their agreements. ${ }^{45}$ In subsequent cases the Board explained the rule as also prohibiting conference rules setting brokerage below $1 \frac{1}{4}$ per cent $^{46}$ or eliminating certain long haul or heavy lift charges from the freight base on which brokerage was estimated. ${ }^{47}$ The Board refused to give weight to conference arguments that, because of competition among conference lines, the result of the Board's policy would be automatic payment of brokerage. ${ }^{48}$ In 1957 the Board, in what appears to foreshadow a change of policy, began to take heed of the conference arguments. In the Pacific Coast European Conf. case ${ }^{49}$ the Board had before it a conference agreement containing a prohibition of brokerage provision similar to that condemned in Agreement 7790.50 The conference refused to comply with the ruling of that case and later cases on the ground that it had not been a party thereto. The Board recognized that approval of the agreement before it would have required an overruling of the policy announced in Agreement 7790 and followed in later cases. ${ }^{51}$ The Board refused to approve the conference agreement, but signified a shift from its prior policy by refusing to order the conference to cease operating under its prohibition of brokerage clause.

${ }^{13}$ Conference prohibition of brokerage in the face of external competition would, of course, favor the competitor-whether an independent or a competing conference. Therefore it is not believed that conferences attempt prohibition where actual or potential competition exists. See note 25 supra.

113 U.S.M.C. at 177.

${ }^{45}$ No order was entered by the Board; the conferences were given time to modify their agreements. Injunctions against the Board were sought in actions brought by conferences on both coasts. The courts denied the relief requested since the Board's findings were not unsupported by the evidence. Pacific Coast Westbound Conf. v. United States, 92 F. Supp. 936 (N.D Calif. 1950), aff'd on rehearing, 94 F. Supp. 649 (N.D. Calif. 1950); Atlantic and Gulf/West Coast Conf. v. United States, 90 F. Supp. 554 (S.D. N.Y. 1950), aff'd on rehearing, 94 F. Supp. 138 (S.D. N.Y. 1950).

46 The opinion of the Board in Agreement 7790, 2 U.S.M.C. 775 (1946), included a finding that $1 \frac{1}{4}$ per cent was a required brokerage amount. In Agreements and Practices $R e$ Brokerage, 3 U.S.M.C. 170, 177 (1949), the Board made a finding to that effect.

17 Joint Board Docket Nos. 718/719. The Joint Committee of Foreign Freight Forwarders Assn. v. Pacific Westbound Conf; Pacific Coast Customs and Freight Brokers Assn. v. Pacific Westbound Conf., 4 F.M.B. 166 (1953).

${ }^{48}$ Agreements and Practices Re Brokerage, 3 U.S.M.C. 170, 174 (1949).

49 5 F.M.B. 225 (1957).

${ }^{\text {so }}$ See text at note 41 supra.

515 F.M.B. at 236. 
Declaring that the premises on which the earlier cases had been decided "may not generally be true today, ${ }^{, 52}$ the Board announced that it would institute a general investigation of brokerage and industry practice regarding automatic payments. The examiner's report in the ensuing investigation ${ }^{53}$ accepted the conference arguments which had been urged unsuccessfully in 1946. To the extent that a prediction of the Board's disposition of the matter is possible, more recent Board statements ${ }^{54}$ would appear to point toward the adoption by the Board of the examiner's report, and thus toward a repudiation of the Board's earlier rule forbidding prohibitory conference regulations.

The Board's general brokerage policy tends to be obscured by the discussion in the cases of prohibitory conference rules. The Board never abandoned its basic position that brokerage was a proper subject of conference regulation. The only conference rules condemned were those that flatly prohibited brokerage under any circumstances. In the leading case, Agreements and Practices Re Brokerage, the Board stated its general view:

Nor is anything herein to be construed as a prohibition against carriers, acting under a conference agreement, from establishing all reasonable rules or regulations which will prevent the payment of brokerage under circumstances which would violate the Act, or as a prohibition against such carriers from placing limitations upon the amounts which they may pay. 55

The Board rule forbidding prohibitory conference rules, although of serious consequence to the carriers since they were compelled to pay automatic brokerage as a result ${ }^{56}$ did not represent a radical shift of policy. The Board remained convinced that conference regulation of brokerage competition among member lines was appropriate and proper.

Not only did the Board continue to approve conference rules forbidding competition within the conferences, but in the Pacific Coast European Conf. case of $1957^{57}$ it suggested that the view first taken in $1936^{58}$ approving the use of brokerage as a device against independents might still be correct. Although the Board refused to approve the conference brokerage rule in the 1957 casethe only case yet litigated directly involving a brokerage rule which was clearly a competitive device against independents-its decision would not appear to have general applicability to all blacklisting regulations. The blacklisting pro-

52 Id. at 237

${ }^{53}$ Examiner's Preliminary Report, Docket No. 831 F.M.B. (March, 1960).

54 The attitude of the Board toward the forwarding industry appears to have hardened in recent years. It is believed that the Examiner's report reflects accurately this changing view. Compare the statement of the Board in Agreements and Practices Re Brokerage, 3 U.S.M.C. 170,174 (1949), with the examiner's conclusions in his report, supra note 53 at 34 . See also cases cited note 11 supra, for Board attitudes toward related brokerage questions.

s5 3 U.S.M.C. 170, 177 (1949) (Emphasis added).

ss See text accompanying note 22 supra.

${ }^{57} 4$ F.M.B. 225 (1957).

${ }^{58}$ In $R e$ Gulf Brokerage and Forwarding Agreements, 1 U.S.S.B.B. 533 (1936) (dictum). See text accompanying note 29 supra. 
vision in Pacific Coast European Conf., ${ }^{59}$ was held prima facie discriminatory because it "would foreclose a nonconference line from obtaining cargo through forwarders in this trade, and shippers who desire to ship nonconference in this trade would be deprived of the services of freight forwarders." that its disapproval was based upon the denial of forwarding services to shippers, and not on the use of brokerage as a competitive device. "We have not considered whether a rule which would merely prohibit payment of brokerage to a broker who actually solicits for or receives brokerage payments from a competing nonconference line would be unjustly discriminatory ... or detrimental to the commerce of the United States. Such a rule might under certain circumstances be shown to be proper and be approved."'61 The inference to be drawn from this dictum is, of course, conjectural in the absence of a specific holding. However, approval of brokerage as a competitive device against independent carriers is consistent with pre-Isbrandtsen Board policy approving dual rate contracts. The dictum would, therefore, appear to reflect Board thinking in this area.

\section{Application of Isbrandtsen to Brokerage Regulation aND} ITS IMPORT FOR FUTURE BOARD POLICY

The foregoing discussion of board policy and industry practice with regard to brokerage indicates the close relationship between conference brokerage rules and competitive forces in liner commerce. Three distinct types of conference rules appear-those establishing uniform conference brokerage rates, those prohibiting brokerage payments, and those using brokerage as a competitive device against independent liner competitors. Of the three types, the Isbrandisen case ${ }^{62}$ would appear to have application only to conference rules using brokerage as a competitive device against independents. In Isbrandtsen the Supreme Court held that dual rate shipping contracts violated Section 14 Third of the Shipping Act "when such practices are used to stifle the competition of independent carriers" ${ }^{63}$ in liner commerce. The Court's construction of section 14 Third does not make clear the breadth of the holding in the case nor does it indicate clearly whether Isbrandtsen will be applied to conference brokerage rules. However it would appear that the principle of decision-that conferences may not by predatory means restrict independent liner operation-has direct application to conference brokerage rules. Section 14 Third of the act prohibits carriers under paragraphs First and Second from granting deferred rebates or utilizing "fighting ships." 64 Both were known conference devices against independents at

59 Discussed supra p. 783.

605 F.M.B. 225, 240 (1957).

${ }^{61} I d$. at 241.

62356 U.S. 481 (1958).

${ }^{63} \mathrm{Id}$. at 495 .

61 A fighting ship was a conference device directly undercutting the rates of a competitor. The conference would select a vessel belonging to one of its members to sail an identical route with the competitor. The conference vessel would sail at rates so low as to drive the competitor out of the trade. The member lines would share the cost of driving out the independent. 
the time the act was passed. Section 14 Third forbids carriers to "retaliate against any shipper by refusing, or threatening to refuse, space accommodations when such are available, or resort to other discriminatory or unfair methods, because such shipper has patronized any other carrier or has filed a complaint charging unfair treatment, or for any other reason." 65 Two arguments suggest that Isbrandtsen may not apply to conference brokerage regulation. First, the basis for the decision may lie in the similarity between the specifically prohibited deferred rebates and dual rates. Since the purpose and effect of each is essentially similar, the Court may have inferred a congressional intent to disapprove both. Secondly, the language of the section appears on its face limited to cases of discrimination or unfairness directed against shippers. By this reasoning Isbrandtsen would, therefore, be inapplicable to brokerage since neither brokers nor independent carriers are protected persons under the section. ${ }^{66}$ These arguments appear to have been rejected by the reasoning of the Isbrandtsen Court which did not read the section so narrowly.

Relying on the legislative history which "brought to light a number of predatory practices by shipping conferences designed to give conferences monopolies upon particular trades by forestalling outside competition and driving out all outsiders attempting to compete," 167 the Court found a congressional plan outlawing "practices of the conferences which have the purpose and effect of stifling the competition of independent carriers." ${ }^{368}$ The Court read section 14 as a protection of independent competition since it prohibited known conference devices against independents. In sections 14 First and Second, Congress barred specific known conference practices that it found undesirable. The first part of section 14 Third also prohibited the known practice of conferences discriminating against shippers using independent services. Viewing the section as a protection of independents the Court found section 14 Third to be a "catch all" provision in which Congress prohibited both conference practices known, but not widely used, and those which might later be developed against independents. The inclusion of "fighting ships" in the prohibited categories supports this construction of the section, since fighting ships were used only against independent carriers and never against shippers. Assuming, as the Court appears to have

6572 Stat. 574 (1958), 46 U.S.C. $§ 812$ (1958) (Emphasis added).

${ }^{66}$ The Court rejected the ejusdem generis argument of the Board which would have related section 14 Third entirely to discriminatory practices of conference against shippers by retaliatory practices. The Court said: "We do not believe that these constructions can be reconciled with the language of the statutes or the scope of the congressional plan." 356 U.S. at 495-96 n.15. However, the view that section 14 Third is restricted to situations in which a shippercarrier tie is involved is supported by the Court's statement early in the opinion that "Congress was unwilling to tolerate methods involving ties between conferences and shippers designed to stifle independent carrier competition." Id. at 492 (Emphasis added). This narrow approach would not achieve the congressional purpose as seen by the Court, and would seem inappropriate in the light of the Court's rejection of the ejicsdem generis argument connecting the retaliation and "resort to" clauses of the section.

${ }^{87}$ Id. at 488 .

${ }^{68} I d$. at 491. 
done, that section 14 in its entirety is a protection of independent liners against conference practices, it would appear unwarranted to limit the application of the section to cases where the conference practices also affect shipper interests. Indeed, the purpose found by the Court would compel the conclusion that the "resort to" clause applies equally to all conference actions found unjust or discriminatory in operation and directed against independent competition.

The Court clearly ruled in Isbrandtsen that the Shipping Act provisions are not a carte blanche to conference regulation of the entire industry, although the Board at times has appeared to think that they are. The Court emphasized "that the freedom allowed conference members to agree upon terms of competition is limited to the freedom to agree upon terms regulating competition among themselves." 69 The dual rate contract struck down in Isbrandtsen was condemned because, like its deferred rebate ancestor, its purpose and effect was predatory and eliminated independent competition. Not all dual rate contracts were condemned in Isbrandtsen-only those found by the Board to be predatory. ${ }^{70}$ The clear implication of the predatory requirement is that the decision rests on the effect of conference practice on independent competition. Deferred rebates, fighting ships and retaliatory denials of shipping space are all specifically prohibited conference activities under the act. The effect of each is the elimination of independent competition. Dual rates were condemned, although not specifically forbidden, for the same reason. It seems clear that conference brokerage regulations destroying independent competition fall within the ambit of prohibited action under Section 14 Third of the Shipping Act. A conference rule blacklisting brokers dealing with independents-such as that impliedly approved in the Pacific Coast European Conf. case ${ }^{71}$-appears, in the light of Isbrandtsen, to be prohibited by the act.

Conference regulation of brokerage competition among member lines, however, appears to be consistent with the policy of the Shipping Act as interpreted in Isbrandtsen. Section 15 of the act provides for the filing of agreements "controlling, regulating, preventing or destroying competition"72 with the Board for approval. The section appears to contemplate conference agreements affecting competition, and clearly implies that the Board has power to approve them. The congressional purpose in passing the act further supports this view. The act was passed in the belief that compensatory rates could be achieved in liner commerce only through price fixing. ${ }^{73}$ Congress selected the private rate-making

${ }^{69}$ Ibid.

${ }^{70} \mathrm{Id}$. at 499. It is of course difficult to conceive of a dual rate system that is not predatory in the Isbrandlsen sense. This does not, however, detract from the doctrinal significance of the "predatory" requirement in construing section 14.

715 F.M.B. 225 (1957).

7262 Stat. 1274 (1950), 46 U.S.C. $\$ 814$ (1958).

${ }^{73}$ See Comment, supra note 5 , at 604-05. 
agreements of conferences as the most appropriate device for accomplishing its purpose. In granting conferences power to make rates without antitrust restriction Congress must also have intended that these rates be made effective. It would be consistent with this purpose that conferences have the power to regulate conditions of competition among members in order to maintain the established rates. Brokerage regulation does aid in maintenance of conference rates and stability, and seems a proper subject of regulation. The Isbrandtsen Court recognized conference power to regulate competition within the conference and interposed no bar to rules limited in their application to internal conference competition. An agreement establishing uniform conference brokerage rates is, therefore, within the Board's power to approve.

Conference rules that prohibit brokerage entirely present a special and diffcult problem. Prohibitory rules, since conferences are apparently unable to impose them in the face of outside competition, ${ }^{74}$ are not "predatory" in the Isbrandisen sense. At the same time their directly detrimental effect upon the forwarding industry, which has no voice in their formulation, would appear to be contrary to antitrust policy. The dilemma of the prohibitory rule is posed by its effect in practice. Permitting such a rule denies forwarder-brokers compensation when properly earned. ${ }^{75}$ On the other hand, absent a prohibitory rule, conference members tend to be forced into payment of brokerage on all shipments automatically. ${ }^{76} \mathrm{Neither}$ result is wholly satisfactory. The difficult problems presented, and the fact that the decision is dependent primarily upon policy considerations-the conference interest in preventing automatic brokerage must be weighed against the forwarder interest in receiving brokerage revenue-would seem to make determination of the proper rule a matter for the Board's expert discretion.

7 See note 25 supra.

${ }^{75}$ The Board in Agreement 7790, 2 U.S.M.C. 775 (1946), took the position that brokerage was payable "only for securing cargo for the ship." This definition was affirmed in Agreements and Practices Re Brokerage, 3 U.S.M.C. 170, 172 (1949).

${ }^{76}$ See text accompanying note 22 supra. 